INDEPENDENT JOURNAL OF MANAGEMENT \& PRODUCTION (IJM\&P)

http://www.ijmp.jor.br

v. 6, n. 2, April - June 2015

ISSN: 2236-269X

DOI: 10.14807/ijmp.v6i2.283

\title{
MADM TECHNIQUE INTEGRATED WITH GREY- BASED TAGUCHI METHOD FOR SELECTION OF ALLUMINIUM ALLOYS TO MINIMIZE DEBURRING COST DURING DRILLING
}

Reddy Sreenivasulu R.V.R. \& J.C.College of Engineering, AndhraPradesh, India E-mail: rslu1431@gmail.com

Goteti Chaitanya R.V.R. \& J.C.College of Engineering, AndhraPradesh, India E-Mail:gotetichaitanya16@gmail.com

Submission: $26 / 11 / 2014$

Revision: 11/12/2014

\section{ABSTRACT}

Accept: 24/12/2014

Traditionally, burr problems had been considered unavoidable so that most efforts had been made on removal of the burr as a post process. Nowadays, a trend of manufacturing is an integration of the whole production flow from design to end product. Manufacturing problem issues are handled in various stages even from design stage. Therefore, the methods of describing the burr are getting much attention in recent years for the systematic approach to resolve the burr problem at various manufacturing stages. The main objective of this paper is to explore the basic concepts of MADM methods. In this study, five parameters namely speed, feed, drill size, drill geometry such as point angle and clearance angle were identified to influence more on burr formation during drilling. L 18 orthogonal array was selected and experiments were conducted as per Taguchi experimental plan for Aluminium alloy of 2014, 6061, 5035 and 7075 series. The experiment performed on a CNC Machining center with HSS twist drills. The burr size such as height and thickness were measured on exit of each hole. An optimal combination of process parameters was obtained to minimize the burr size via grey relational analysis. The output from grey based- Taguchi method fed as input to 
INDEPENDENT JOURNAL OF MANAGEMENT \& PRODUCTION (IJM\&P)

http://www.ijmp.jor.br

v. 6, n. 2, April - June 2015

ISSN: 2236-269X

DOI: $10.14807 /$ ijmp.v6i2.283

the MADM. Apart from burr size strength and temperature are also considered as attributes. Finally, the results generated in MADM suggests the suitable alternative of aluminium alloy, which results in less debugging cost, high strength and high resistance at elevated temperatures.

Keywords: Drilling, Aluminium alloys, Grey based Taguchi method, AHP, TOPSIS.

\section{INTRODUCTION}

Most of the industries perform a huge number of drilling operations in shop floor. The drilling technology has been discussed to improve the cutting performance with optimizing the cutting parameters and the drill geometry. However, burr size is sometimes formed when the drill exits the work piece and the exit burrs have to be removed in the debugging process. The control of exit burr formation, therefore, has been strongly required to reduce the post process of the drilling operation.

A burr is formed due to incompleteness of cutting mechanism during machining process in general. Machining is not necessarily only the process creating the burr but it is the most concerned process in the burr related industry and academic researchers. All machining processes intend to process a raw material or partially shaped work piece material into a designed shape with a specific size and tolerance. Fundamental weaknesses in machining processes that a cutting always requires sustainable work piece materials, however, causes bending or break-off of the work piece material.

The result of the former is the burr and that of the latter is the edge break. Therefore, the burr, an unintended outcome of machining processes (PANDE; RELEKAR, 1986; LAUDERBAUGH, 2008), has been a widely recognized problem to the industry. It ruins the integrity of design of the part, requires additional processes to assemble it, causes safety hazards, and results in malfunction of the product. All these side effects causes unnecessary cost to the industry in various forms such as additional machining, compensation, service, redesign, and collateral damage on the company goodwill.

Therefore, in most cases, it is a must either to remove or to secure the burr in order to prevent it from being detached from the part. Traditionally, burr problems had been considered unavoidable so that most efforts had been made on removal of the burr as a post process. Naturally, many de burring processes have been 
INDEPENDENT JOURNAL OF MANAGEMENT \& PRODUCTION (IJM\&P)

http://www.ijmp.jor.br

v. 6, n. 2, April - June 2015

ISSN: 2236-269X

DOI: 10.14807/ijmp. v6i2.283

developed (KO; LEE, 2001) and for their effectiveness and competitiveness, many researchers have been conducted.

Nowadays, a trend of manufacturing is an integration of the whole production flow from design to end product. Manufacturing problem issues are handled in various stages, even from design stage. Therefore, the methods of describing the burr are getting much attention in recent years for the systematic approach to resolve the burr problem at various manufacturing stages.

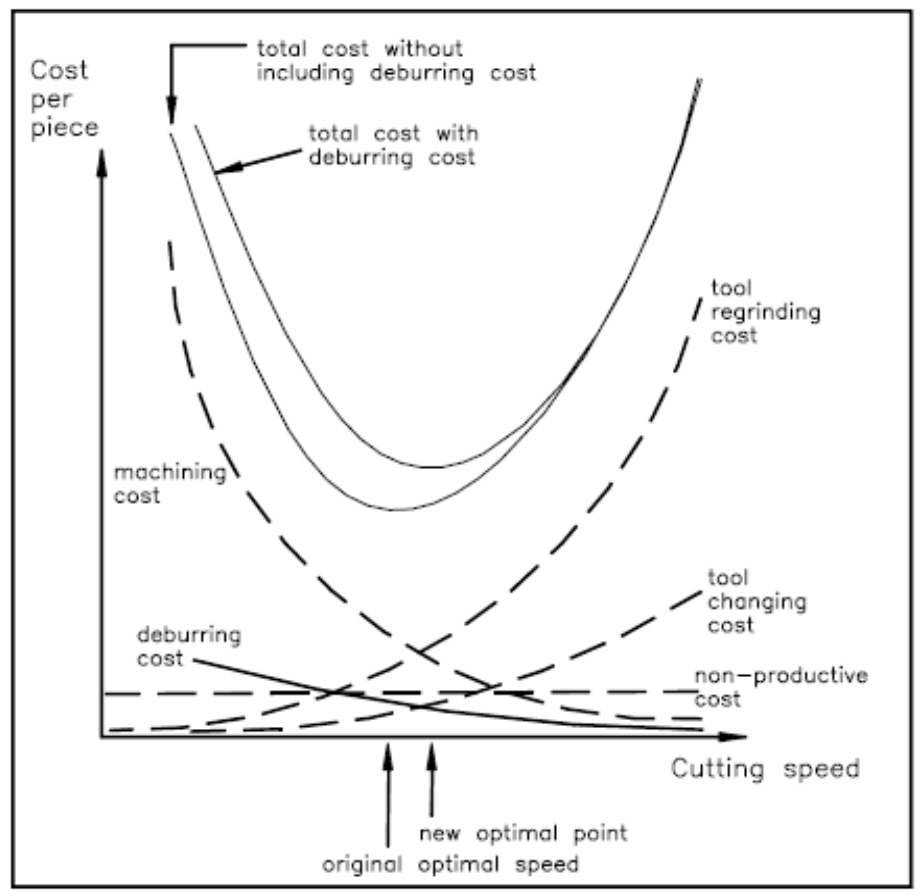

Figure 1: Effect of deburring cost in to part cost

\section{BACK GROUND OF ALUMINIUM ALLOYS:}

At present, aluminium is used in the aviation industry everywhere in the world. The casing of the first Soviet satellite was made of aluminium alloys. The body casing of American 'Avant-garde' and 'Titan' rockets used for launching the first American rockets into the orbit, and later on - spaceships, was also made of aluminium alloys. They are used for manufacturing various components of spaceship equipment: brackets, fixtures, chassis, covers and casing for many tools and devices.

Aluminium alloys (HAMADE; ISMAIL, 2005) have a certain advantage for creating space equipment units. High values of specific strength and the specific rigidity of the material enabled the tanks, inter-tank and casing of the rocket to be manufactured with high longitudinal stability. The advantages of aluminium alloys also include their high performance under cryogen temperatures in contact with liquid 
INDEPENDENT JOURNAL OF MANAGEMENT \& PRODUCTION (IJM\&P)

http://www.ijmp.jor.br

v. 6, n. 2, April - June 2015

ISSN: 2236-269X

DOI: 10.14807/ijmp. v6i2.283

oxygen, hydrogen, and helium. The so-called cryogen reinforcement happens in these alloys, i.e. the strength and flexibility increase parallel to the decreasing temperature. Engineers and manufacturers never cease to study the properties of aluminium, developing more and more new alloys for construction of aircraft and spaceships. 2xxx, 5xxx, 6xxx, and 7xxx series alloys are widely used in aviation.

\section{METHODOLOGY}

\subsection{Grey based - taguchi method:}

The integrated grey based Taguchi method combines advantages of both grey relational analysis and Taguchi method (DENG, 1989; MONTGOMERY, 2007). This method was successfully applied to optimize the multi response of complicated problems in manufacturing processes. Furthermore, ANOVA is performed to see which process parameters are statistically significant. The integrated grey based Taguchi method combines the algorithm of Taguchi method and grey relational analysis to determine process parameters for multiple responses.

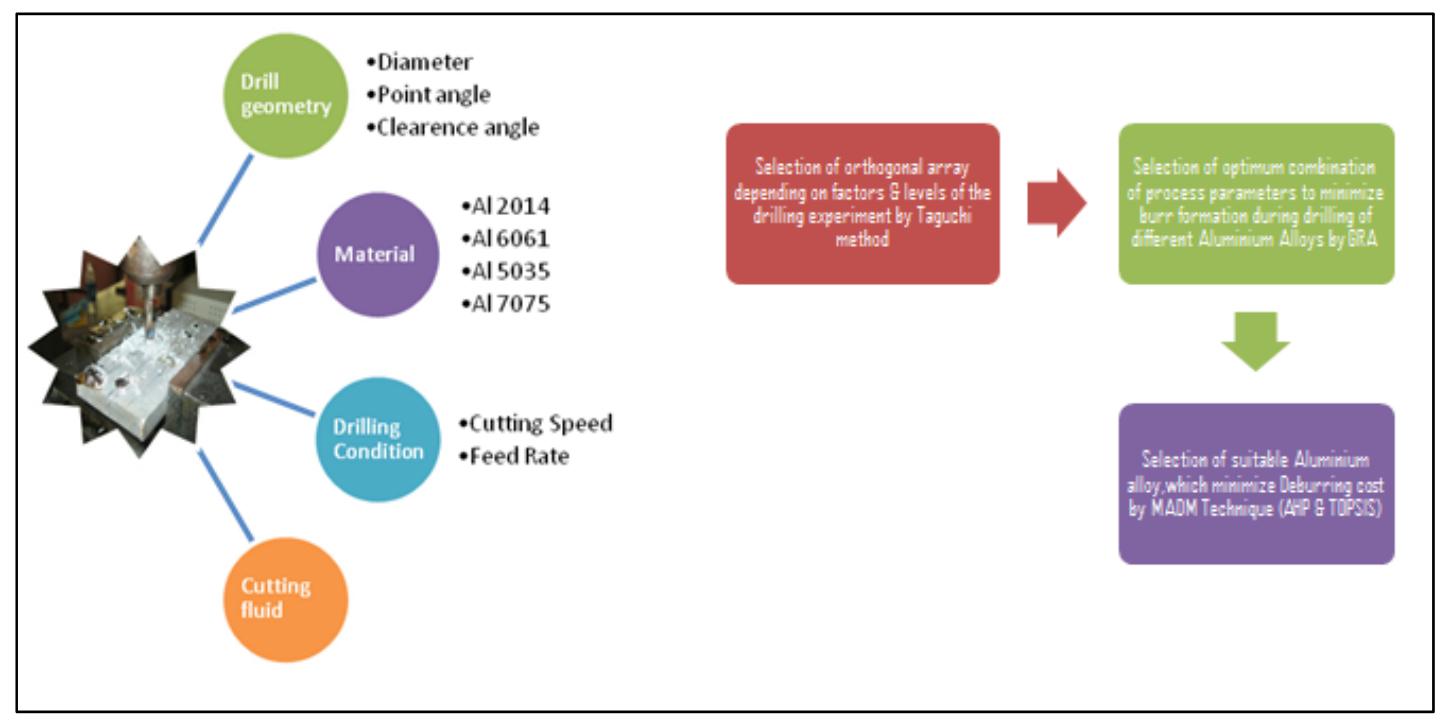

Figure 2: Influential Factors on burr formation in drilling \&block diagram of MADM integrated with grey based-Taguchi method

\subsection{Multi-Attribute Decision Making (MADM) Technique:}

Decision making is the study of identifying and choosing alternatives based on the values and preferences of the decision maker. Making a decision implies that there are alternative choices to be considered, and in such a case, not only as many of these alternatives as possible are identified but also the best one is chosen to meet the 
INDEPENDENT JOURNAL OF MANAGEMENT \& PRODUCTION (IJM\&P)

http://www.ijmp.jor.br

v. 6, n. 2, April - June 2015

ISSN: 2236-269X

DOI: 10.14807/ijmp.v6i2.283

decision maker's goals, objectives, desires, and values (HWANG; YOON, 1982; CHEN; HWANG, 1992; YOON; HWANG, 1995).

Thus, every decision making process produces a final choice. The selection decisions are complex, as decision making is more challenging now a days. For obtaining the best decision in conjunction with the real-time requirements, a number of MADM approaches are available. MADM methods (SAATY, 2000; OLSON, 2004; KUMAR; SUMAN, 2014) are generally discrete, with a limited number of pre-specified alternatives.

These methods require both intra and inter-attribute comparisons, and involve explicit tradeoffs that are appropriate for the problem considered. Most commonly used MADM approaches are weighted sum method (WSM), weighted product method (WPM), Analytic hierarchy process (AHP), Technique for order preference by similarity to ideal solution (TOPSIS), and Compromise ranking method (VIKOR), Graph theoretic approach (GTA).

The main objective of this paper is to explore the basic concepts of MADM methods. From the literature it is clear that Analytic hierarchy process (AHP), Technique for order preference by similarity to ideal solution (TOPSIS) approach as a decision making method is relatively new, and offers a generic, simple, easy, and convenient decision making method that involves less computation.

The main procedure of the combined TOPSIS and AHP method is as follows:

- Step 1: Determine the objective and evaluation attributes. In the present case, $2 x x x, 5 x x x, 6 x x x$, and $7 x x x$ series of aluminium alloys on the basis of the attributes such as deburring cost, strength and temperature satisfying the requirements.

- Step 2: Formulate a decision matrix with each alternative as a row and each column to one attribute. Therefore, an element dij of the decision matrix " $D$ " gives the value of the jth attribute in original real values, that is, nonnormalized form and units, for the ith alternative. Thus, if the number of alternatives is "M" and the number of attributes in "N", then the decision matrix is an $\mathrm{M} \times \mathrm{N}$ matrix can be represented as: 
INDEPENDENT JOURNAL OF MANAGEMENT \& PRODUCTION (IJM\&P)

http://www.ijmp.jor.br

v. 6, n. 2, April - June 2015

ISSN: 2236-269X

DOI: 10.14807/ijmp.v6i2.283

$$
D_{M X N}=\begin{array}{r}
\text { Attribute } 1 \\
1 \\
2 \\
2 \\
3 \\
\ldots \\
M
\end{array}\left[\begin{array}{cccccc}
d_{11} & d_{12} & d_{13} & \ldots & \ldots & N \\
d_{21} & d_{22} & d_{23} & \ldots & \ldots & d_{1 N} \\
d_{31} & d_{32} & d_{33} & \ldots & \ldots & d_{3 N} \\
\ldots & \ldots & \ldots & \ldots & \ldots & \ldots \\
\ldots & \ldots & \ldots & \ldots & \ldots & \ldots \\
d_{M 1} & d_{M 2} & d_{M 3} & \ldots & \ldots & d_{M N}
\end{array}\right]
$$

- Step 3: Obtain the normalized decision matrix, Rij. This can be represented

$$
R_{i j}=\frac{d_{i j}}{\left\{\sum_{j=1}^{M} d_{i j}^{2}\right\}^{0.3}}
$$

- Step 4: 1. Find out the relative importance of different attributes with respect to the objective. To do so, one has to construct a pair-wise comparison matrix using a scale of relative importance. The results are entered using the fundamental scale of the analytic hierarchy process. An attribute (material) compared with it is always assigned the value 1 so the main diagonal entries of the pair-wise comparison matrix are all 1 . The numbers $3,5,7$, and 9 correspond to the verbal judgments "less importance", "medium importance", "more importance", and "ideal importance" (with 2, 4, 6, and 8 for compromise between the previous values). Assuming $\mathrm{N}$ attributes, the pair wise comparison of attribute $i$ with attribute $j$ yields a square matrix $A_{N} \times N$ where aij denotes the comparative importance of attribute $\mathrm{i}$ with respect to attribute $\mathrm{j}$. In the matrix, aij=1 when $\mathrm{i}=\mathrm{j}$ and $\mathrm{aji}=1 /$ aij.. This can be described as

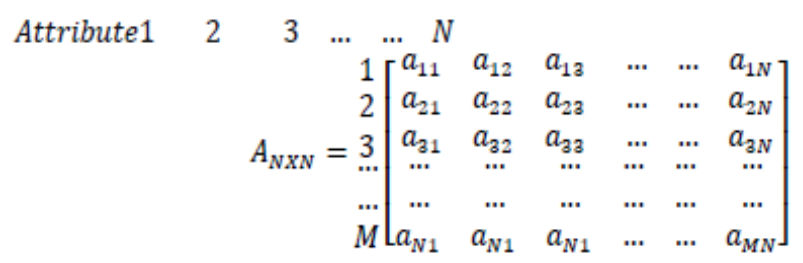

The relative normalized weight $(\mathrm{Wj})$ of each attribute by (i) calculating the geometric mean of ith row and (ii) normalizing the geometric means of rows in the comparability matrix. This can be represented as

$$
G M_{i}=\left\{\prod_{j=1}^{N} a_{i j}\right\}^{1 / N}
$$$$
\text { and } \quad W_{j}=G M_{i} / \sum_{i=1}^{N} G M_{i}
$$

The geometric mean method of AHP is used in the present work to find out the relative normalized weights of the attributes because of its simplicity and easiness to find out the maximum Eigen value and to reduce the inconsistency in judgments. 
INDEPENDENT JOURNAL OF MANAGEMENT \& PRODUCTION (IJM\&P)

http://www.ijmp.jor.br

v. 6, n. 2, April - June 2015

ISSN: 2236-269X

DOI: 10.14807/ijmp. v6i2.283

2. Calculate matrix $A 3$ and $A 4$ such that $A 3=A 1 \times A 2$ and $A 4=A 3 / A 2$, where $\mathrm{A} 2=[\mathrm{W} 1, \mathrm{~W} 2 \ldots \mathrm{WN}] \mathrm{T}$.

3. Find out the maximum Eigen value $\lambda \max$ that is the average of matrix $A 4$.

4. Calculate the consistency index $\mathrm{Cl}=(\lambda \max -\mathrm{N}) /(\mathrm{N}-1)$. The smaller the value of $\mathrm{Cl}$, the smaller is the deviation from the consistency.

5. Obtain the random index $(\mathrm{RI})$ for the number of attributes used in decision making.

6. Calculate the consistency ratio $\mathrm{CR}=\mathrm{Cl} / \mathrm{RI}$. Usually, a $\mathrm{CR}$ of 0.1 or less is considered as acceptable and it reflects an informed judgment that could be attributed to the knowledge of the analyst about the problem under study.

- Step 5: Obtain the weighted normalized matrix Vij. This is obtained by the multiplication of each element of the column of the matrix Rij with its associated weight Wj. Hence, the elements of the weighted normalized matrix Vij are expressed as $\mathrm{Vij}=\mathrm{Wj} \mathrm{Rij}$.

- Step 6: Obtain the Ideal (best) and Negative-Ideal (worst) solutions in this step. The ideal (best) and negative ideal (worst) solution can be expressed as

$$
\begin{aligned}
V^{+} & =\left\{\left(\sum_{i}^{\max } V_{i j} / j \in J\right),\left(\sum_{i}^{\min } V_{i j} / j \in J\right) / i=1,2, M\right\} \\
= & \left\{V_{1}^{+}, V_{2}^{+}, V_{3}^{+}, \ldots \ldots \ldots, V_{N}^{+}\right\} \\
& V^{-}=\left\{\left(\sum_{i}^{\min } V_{i j} / j \in J\right),\left(\sum_{i}^{\max } V_{i j} / j \in J^{\prime}\right) i=1,2, M\right\} \\
& =\left\{V_{1}^{-}, V_{2}^{-}, V_{3}^{-}, \ldots \ldots \ldots, V_{N}^{-}\right\}
\end{aligned}
$$

- Step 7: Obtain the separation measures. The separation of each alternative from the ideal one is given by Euclidean distance by the following equations.

$$
\begin{aligned}
& S_{i}^{+}=\left\{\sum_{J=1}^{N}\left(V_{i j}-V_{j}^{+}\right)^{2}\right\}^{0.5}, i=1,2,3 \ldots \ldots \ldots, \mathrm{M} \\
& S_{i}^{-}=\left\{\sum_{J=1}^{N}\left(V_{i j}-V_{j}^{-}\right)^{2}\right\}^{0.5}, \mathrm{i}=1,2,3 \ldots \ldots \ldots, \mathrm{M}
\end{aligned}
$$

- Step 8: The relative closeness of a particular alternative to the ideal solution can be expressed in this step as follows.

$$
C_{i}=S_{i}^{-} /\left(S_{i}^{+}+S_{i}^{-}\right)
$$

- Step 9: A set of alternatives is made in the descending order in this step, according to the preference value indicating the most preferred and least preferred feasible solutions. 
INDEPENDENT JOURNAL OF MANAGEMENT \& PRODUCTION (IJM\&P)

http://www.ijmp.jor.br

v. 6, n. 2, April - June 2015

ISSN: 2236-269X

DOI: 10.14807/ijmp. v6i2.283

- Step 10: Take a final decision keeping in view the practical considerations. All possible constraints likely to be experienced by the user are looked in during this stage.

\section{OBSERVATIONS AND RESULTS:}

In this study, the experiments were carried out on a CNC vertical machining center (KENT and ND Co. Ltd, Taiwan make) to perform different size of holes on Al6061, 2014, 5035, 7075 work pieces by alter the point and clearance angles on standard HSS twist drill bits and maintain constant helix angle of 45 degrees. Furthermore the cutting speed $(\mathrm{m} / \mathrm{min})$, the feed rate $(\mathrm{mm} / \mathrm{rev})$ and percentage of cutting fluid mixture ratio are regulated in this experiment. The burr size (thickness, R1 and height, R2) is measured by digital profile projector. The machining parameters and their levels are given in table1. Plan of experiments based on Taguchi orthogonal array and observed responses shown in table 2.

Table1: Machining parameters and their levels

\begin{tabular}{|c|c|c|c|c|c|}
\hline \multirow{2}{*}{ Levels } & \multicolumn{5}{|c|}{ FACTORS } \\
\cline { 2 - 6 } & $\begin{array}{c}\text { Cutting Speed } \\
(\mathrm{mm} / \mathrm{min})\end{array}$ & $\begin{array}{c}\text { Feed Rate } \\
(\mathrm{mm} / \mathrm{min})\end{array}$ & $\begin{array}{c}\text { Drill Diameter } \\
(\mathrm{mm})\end{array}$ & $\begin{array}{c}\text { Point Angle } \\
(\text { Degrees })\end{array}$ & $\begin{array}{c}\text { Clearance Angle } \\
\text { (Degrees) }\end{array}$ \\
\cline { 2 - 6 } & $\mathrm{A}$ & $\mathrm{B}$ & $\mathrm{C}$ & $\mathrm{D}$ & $\mathrm{E}$ \\
\hline 1 & 15.08 & 0.3 & 8 & 118 & 4 \\
\hline 2 & 25.13 & 0.5 & 10 & 110 & 6 \\
\hline 3 & 37.7 & 0.6 & 12 & 100 & 8 \\
\hline
\end{tabular}

Table 2: Plan of experiments based on Taguchi orthogonal array and observed responses

\begin{tabular}{|c|c|c|c|c|c|c|c|c|c|c|c|c|c|}
\hline \multirow[t]{2}{*}{ Runs } & \multirow[t]{2}{*}{ A } & \multirow[t]{2}{*}{ B } & \multirow[t]{2}{*}{ C } & \multirow[t]{2}{*}{ D } & \multirow[t]{2}{*}{$E$} & \multicolumn{2}{|c|}{$\begin{array}{l}\text { Al } 6061 \\
\text { Measured } \\
\text { Responses }\end{array}$} & \multicolumn{2}{|c|}{$\begin{array}{l}\text { Al } 2014 \\
\text { Measured } \\
\text { Response } \\
\text { s }\end{array}$} & \multicolumn{2}{|c|}{$\begin{array}{l}\text { Al } 5035 \\
\text { Measured } \\
\text { Responses }\end{array}$} & \multicolumn{2}{|c|}{$\begin{array}{l}\text { Al } 7075 \\
\text { Measured } \\
\text { Responses }\end{array}$} \\
\hline & & & & & & $\mathrm{R}_{1}$ & $\mathrm{R}_{2}$ & $\mathrm{R}_{1}$ & $\mathrm{R}_{2}$ & $\mathrm{R}_{1}$ & $\mathrm{R}_{2}$ & R1 & $\mathrm{R} 2$ \\
\hline 1 & 1 & 1 & 1 & 1 & 1 & 0.28 & 0.18 & 0.21 & $\begin{array}{c}0.2 \\
6\end{array}$ & 0.34 & 0.35 & 0.36 & $\begin{array}{c}0.4 \\
1\end{array}$ \\
\hline 2 & 1 & 2 & 2 & 2 & 2 & 0.27 & 0.16 & 0.24 & $\begin{array}{c}0.3 \\
4\end{array}$ & 0.38 & 0.46 & 0.44 & $\begin{array}{c}0.3 \\
7\end{array}$ \\
\hline 3 & 1 & 3 & 3 & 3 & 3 & 0.30 & 0.18 & 0.29 & $\begin{array}{c}0.4 \\
4\end{array}$ & 0.31 & 0.52 & 0.33 & $\begin{array}{c}0.4 \\
6\end{array}$ \\
\hline 4 & 2 & 1 & 1 & 2 & 2 & 0.29 & 0.20 & 0.35 & 0.3 & 0.43 & 0.44 & 0.35 & 0.4 \\
\hline
\end{tabular}


INDEPENDENT JOURNAL OF MANAGEMENT \& PRODUCTION (IJM\&P)

http://www.ijmp.jor.br

v. 6 , n. 2, April - June 2015

ISSN: 2236-269X

DOI: 10.14807/ijmp.v6i2.283

\begin{tabular}{|c|c|c|c|c|c|c|c|c|c|c|c|c|c|}
\hline & & & & & & & & & 8 & & & & 4 \\
\hline 5 & 2 & 2 & 2 & 3 & 3 & 0.25 & 0.16 & 0.28 & $\begin{array}{c}0.2 \\
3\end{array}$ & 0.44 & 0.45 & 0.38 & $\begin{array}{c}0.5 \\
0\end{array}$ \\
\hline 6 & 2 & 3 & 3 & 1 & 1 & 0.26 & 0.19 & 0.22 & $\begin{array}{c}0.3 \\
1\end{array}$ & 0.41 & 0.40 & 0.43 & $\begin{array}{c}0.4 \\
1\end{array}$ \\
\hline 7 & 3 & 1 & 2 & 1 & 3 & 0.19 & 0.15 & 0.19 & $\begin{array}{c}0.3 \\
7\end{array}$ & 0.39 & 0.30 & 0.45 & $\begin{array}{c}0.5 \\
4\end{array}$ \\
\hline 8 & 3 & 2 & 3 & 2 & 1 & 0.35 & 0.23 & 0.23 & $\begin{array}{c}0.4 \\
3\end{array}$ & 0.33 & 0.34 & 0.52 & $\begin{array}{c}0.3 \\
3\end{array}$ \\
\hline 9 & 3 & 3 & 1 & 3 & 2 & 0.24 & 0.18 & 0.34 & $\begin{array}{c}0.3 \\
8\end{array}$ & 0.48 & 0.34 & 0.51 & $\begin{array}{c}0.5 \\
6\end{array}$ \\
\hline 10 & 1 & 1 & 3 & 3 & 2 & 0.31 & 0.24 & 0.33 & $\begin{array}{c}0.4 \\
0\end{array}$ & 0.39 & 0.43 & 0.48 & $\begin{array}{c}0.3 \\
6\end{array}$ \\
\hline 11 & 1 & 2 & 1 & 1 & 3 & 0.22 & 0.15 & 0.36 & $\begin{array}{c}0.3 \\
9\end{array}$ & 0.37 & 0.44 & 0.41 & $\begin{array}{c}0.4 \\
6\end{array}$ \\
\hline 12 & 1 & 3 & 2 & 2 & 1 & 0.32 & 0.20 & 0.27 & $\begin{array}{c}0.3 \\
3\end{array}$ & 0.39 & 0.42 & 0.43 & $\begin{array}{c}0.4 \\
0\end{array}$ \\
\hline 13 & 2 & 1 & 2 & 3 & 1 & 0.23 & 0.15 & 0.30 & $\begin{array}{c}0.3 \\
4\end{array}$ & 0.42 & 0.46 & 0.49 & $\begin{array}{c}0.4 \\
9\end{array}$ \\
\hline 14 & 2 & 2 & 3 & 1 & 2 & 0.20 & 0.15 & 0.38 & $\begin{array}{c}0.2 \\
8\end{array}$ & 0.41 & 0.51 & 0.52 & $\begin{array}{c}0.5 \\
1\end{array}$ \\
\hline 15 & 2 & 3 & 1 & 2 & 3 & 0.18 & 0.16 & 0.35 & $\begin{array}{c}0.3 \\
8\end{array}$ & 0.48 & 0.43 & 0.56 & $\begin{array}{c}0.3 \\
6\end{array}$ \\
\hline 16 & 3 & 1 & 3 & 2 & 3 & 0.33 & 0.22 & 0.31 & $\begin{array}{c}0.1 \\
8\end{array}$ & 0.36 & 0.37 & 0.53 & $\begin{array}{c}0.3 \\
7\end{array}$ \\
\hline 17 & 3 & 2 & 1 & 3 & 1 & 0.21 & 0.14 & 0.32 & $\begin{array}{c}0.2 \\
1\end{array}$ & 0.39 & 0.41 & 0.57 & $\begin{array}{c}0.4 \\
2\end{array}$ \\
\hline 18 & 3 & 3 & 2 & 1 & 2 & 0.24 & 0.21 & 0.25 & $\begin{array}{c}0.2 \\
2\end{array}$ & 0.36 & 0.39 & 0.47 & $\begin{array}{c}0.3 \\
6\end{array}$ \\
\hline
\end{tabular}

Table3: Optimal combination of parameters to minimize burr size by integrated grey based Taguchi method

\begin{tabular}{|c|c|c|c|}
\hline Material & $\begin{array}{c}\text { Optimal combination of } \\
\text { parameters }\end{array}$ & Burr height $(\mathrm{mm})$ & Burr thickness $(\mathrm{mm})$ \\
\hline Al 6061 & A2B2C1D1E3 & 0.16 & 0.11 \\
\hline Al 7075 & A3B2C2D2E2 & 0.33 & 0.26 \\
\hline Al 5035 & A1B1C3D3E1 & 0.26 & 0.24 \\
\hline Al2014 & A1B2C1D1E3 & 0.17 & 0.14 \\
\hline
\end{tabular}


INDEPENDENT JOURNAL OF MANAGEMENT \& PRODUCTION (IJM\&P)

http://www.ijmp.jor.br

v. 6, n. 2, April - June 2015

ISSN: 2236-269X

DOI: 10.14807/ijmp. v6i2.283

The results obtained in integrated grey based Taguchi method are given into the input for MADM apart from mechanical properties (resistance to corrosion, resistance to high temperature, fatigue strength, ultimate tensile strength, hardness) of Al 6061, 7075, 5035, 2014 alloys are also considered for air craft applications from previous literature, those weights are taken as per the importance of respective properties.

Then the Decision Matrix, $C=$
$[0.1600$
0.1100
3.0000
1.0000
3.0000
3.0000
2.0000
0.3000
0.2600
2.0000
2.0000
1.0000
1.00001 .0000
0.2600
0.2400
1.0000
3.0000
4.0000
$4.0000 \quad 3.0000$
0.1700
$0.1400 \quad 4.0000$
$4.0000 \quad 2.0000$
$2.0000 \quad 4.0000]$

$\operatorname{Normalized} \operatorname{Matrix}(N)=$
$\left[\begin{array}{ll}1.0000 & 1.0000\end{array}\right.$
0.7500
0.2500
0.7500
0.7500
0.5000
$0.5333 \quad 0.4231$
0.5000
0.5000
0.2500
0.2500
0.2500
0.6154
0.4583
0.2500
0.7500
$1.0000 \quad 1.0000$
0.7500
0.9412
0.7857
1.0000
$1.0000 \quad 0.5000$
0.5000
1.0000]

Normalized decision matrix, $R i=$
[1.0000
4.0000
2.0000
6.0000
3.0000
$4.0000 \quad 3.0000$
$0.2500 \quad 1.0000$
$1.0000 \quad 3.0000$
6.0000
5.0000
8.0000
0.5000
1.0000
1.0000
2.0000
6.0000
$4.0000 \quad 4.0000$
0.1667
0.3333
0.5000
1.0000
1.0000
$3.0000 \quad 3.0000$
0.3333
0.1667
0.1667
1.00001 .0000
2.0000
2.0000
0.2500
0.2000
0.2500
0.3333
0.5000
$1.0000 \quad 1.0000$
0.3333
0.1250
0.2500
0.3333
0.5000
$\begin{array}{ll}1.0000 & 1.0000]\end{array}$

\subsection{AHP Result:}

Pair wise comparison 
INDEPENDENT JOURNAL OF MANAGEMENT \& PRODUCTION (IJM\&P)

http://www.ijmp.jor.br

V. 6, n. 2, April - June 2015

ISSN: 2236-269X

DOI: 10.14807/ijmp. v6i2.283
$\operatorname{pwc}(:,:, 1)=$
$p w c(:,:, 6)=$
$\begin{array}{llllllll}1.0000 & 1.8750 & 1.6250 & 1.0625 & 1.0000 & 3.0000 & 0.7500 & 1.5000\end{array}$
$\begin{array}{llllllll}0.5333 & 1.0000 & 0.8667 & 0.5667 & 0.3333 & 1.0000 & 0.2500 & 0.5000\end{array}$
$\begin{array}{llllllll}0.6154 & 1.1538 & 1.0000 & 0.6538 & 1.3333 & 4.0000 & 1.0000 & 2.0000\end{array}$
$\begin{array}{llllllll}0.9412 & 1.7647 & 1.5294 & 1.0000 & 0.6667 & 2.0000 & 0.5000 & 1.0000\end{array}$
pwc $(:,:, 2)=$
$p w c(:,:, 7)=$

$\begin{array}{llllllll}1.0000 & 2.3636 & 2.1818 & 1.2727 & 1.0000 & 2.0000 & 0.6667 & 0.5000 \\ 0.4231 & 1.0000 & 0.9231 & 0.5385 & 0.5000 & 1.0000 & 0.3333 & 0.2500 \\ 0.4583 & 1.0833 & 1.0000 & 0.5833 & 1.5000 & 3.0000 & 1.0000 & 0.7500 \\ 0.7857 & 1.8571 & 1.7143 & 1.0000 & 2.0000 & 4.0000 & 1.3333 & 1.0000\end{array}$
$\operatorname{pwc}(:,:, 3)=$
$p w c(:,:, 8)=$
$\begin{array}{llllllll}1.0000 & 1.5000 & 3.0000 & 0.7500 & 0.3236 & 0.1726 & 0.1992 & 0.3046\end{array}$
$\begin{array}{llllllll}0.6667 & 1.0000 & 2.0000 & 0.5000 & 0.3749 & 0.1586 & 0.1718 & 0.2946\end{array}$
$\begin{array}{llllllll}0.3333 & 0.5000 & 1.0000 & 0.2500 & 0.3000 & 0.2000 & 0.1000 & 0.4000\end{array}$
$\begin{array}{llllllll}1.3333 & 2.0000 & 4.0000 & 1.0000 & 0.1000 & 0.2000 & 0.3000 & 0.4000\end{array}$
$\operatorname{pwc}(:,:, 4)=$
$0.3000 \quad 0.1000 \quad 0.4000 \quad 0.2000$
$\begin{array}{llllllll}1.0000 & 0.5000 & 0.3333 & 0.2500 & 0.3000 & 0.1000 & 0.4000 & 0.2000\end{array}$
$\begin{array}{llllllll}2.0000 & 1.0000 & 0.6667 & 0.5000 & 0.2000 & 0.1000 & 0.3000 & 0.4000\end{array}$
$\begin{array}{llll}3.0000 & 1.5000 & 1.0000 & 0.7500\end{array}$
$\begin{array}{llll}4.0000 & 2.0000 & 1.3333 & 1.0000\end{array}$
$\operatorname{pwc}(:,:, 5)=$
$1.0000 \quad 3.0000$
$0.7500 \quad 1.5000$
$\begin{array}{llll}0.3333 & 1.0000 & 0.2500 & 0.5000\end{array}$
$\begin{array}{llll}1.3333 & 4.0000 \quad 1.0000 & 2.0000\end{array}$
$\begin{array}{llll}0.6667 & 2.0000 & 0.5000 & 1.0000\end{array}$ 
INDEPENDENT JOURNAL OF MANAGEMENT \& PRODUCTION (IJM\&P)

http://www.ijmp.jor.br

v. 6, n. 2, April - June 2015

ISSN: 2236-269X

DOI: 10.14807/ijmp.v6i2.283

$p 1=$

$\left[\begin{array}{lllllll}0.3236 & 0.3749 & 0.3000 & 0.1000 & 0.3000 & 0.3000 & 0.2000\end{array}\right.$

$\begin{array}{lllllll}0.1726 & 0.1586 & 0.2000 & 0.2000 & 0.1000 & 0.1000 & 0.1000\end{array}$

$\begin{array}{lllllll}0.1992 & 0.1718 & 0.1000 & 0.3000 & 0.4000 & 0.4000 & 0.3000\end{array}$

$\begin{array}{lllllll}0.3046 & 0.2946 & 0.4000 & 0.4000 & 0.2000 & 0.2000 & 0.4000]\end{array}$

AHP matrix final $=$

0.3023

0.1662

0.2083

0.3231

AHPdisrank =

$\begin{array}{llll}4 & 1 & 3 & 2\end{array}$

3.2. TOPSIS Method

$s u=$

$\begin{array}{lllllll}0.4605 & 0.3961 & 5.4772 & 5.4772 & 5.4772 & 5.4772 & 5.4772\end{array}$ $r=$

$\begin{array}{lllllll}0.3474 & 0.2777 & 0.5477 & 0.1826 & 0.5477 & 0.5477 & 0.3651\end{array}$

$\begin{array}{lllllll}0.6514 & 0.6564 & 0.3651 & 0.3651 & 0.1826 & 0.1826 & 0.1826\end{array}$

$\begin{array}{lllllll}0.5646 & 0.6059 & 0.1826 & 0.5477 & 0.7303 & 0.7303 & 0.5477\end{array}$

$\begin{array}{lllllll}0.3691 & 0.3534 & 0.7303 & 0.7303 & 0.3651 & 0.3651 & 0.7303\end{array}$

$w m=$

$\begin{array}{lllllll}0.3159 & 0.2287 & 0.2090 & 0.0893 & 0.0680 & 0.0451 & 0.0439\end{array}$ $v v=$

$\begin{array}{lllllll}0.1098 & 0.0635 & 0.1145 & 0.0163 & 0.0373 & 0.0247 & 0.0160\end{array}$

$\begin{array}{lllllll}0.2058 & 0.1501 & 0.0763 & 0.0326 & 0.0124 & 0.0082 & 0.0080\end{array}$

$\begin{array}{lllllll}0.1783 & 0.1386 & 0.0382 & 0.0489 & 0.0497 & 0.0329 & 0.0241\end{array}$ 
INDEPENDENT JOURNAL OF MANAGEMENT \& PRODUCTION (IJM\&P)

http://www.ijmp.jor.br

v. 6, n. 2, April - June 2015

ISSN: 2236-269X

DOI: 10.14807/ijmp. v6i2.283
0.1166
0.0808
$0.1527 \quad 0.0652$
0.0248
0.0165
0.0321

vplus $=$
0.1098
0.0635
0.1527
0.0652
$0.0497 \quad 0.0329$
0.0321

vminus $=$

0.2058

0.1501

$0.0382 \quad 0.0163$

0.0124

0.0082

0.0080

\begin{tabular}{|c|c|c|c|}
\hline siplus $=$ & 0.0658 & 0.1618 & 0.1542 \\
\hline siminus $=$ & 0.1533 & 0.0415 & 0.0648 \\
\hline Topsis matrix $=$ & 0.6997 & 0.2041 & 0.2960 \\
\hline
\end{tabular}

\section{CONCLUDING REMARKS:}

Burr formation during drilling is a serious problem while assembly of precision components. Majority of aerospace, automobile and marine industries use aluminium alloys. In this paper, a study on the optimal selection of aluminium alloys especially for aerospace industry to minimize the debugging cost (cost incurred for post processing of burr formation on exit of drilled holes) is carried out. In this connection, MADM technique is proposed for decision making regarding selection of suitable material which yields minimal burr size, high strength and high temperature resistant.

Initially, the optimum burr size is estimated using grey based- Taguchi method for different series of aluminium alloys. The output from grey based- Taguchi method fed as input to the MADM. Apart from burr size strength and temperature are also considered as attributes. Finally, the results generated in MADM suggests the suitable alternative choice of aluminium alloys in a rank wise $(2014,6061,5035,7075$ in an order) in both AHP and TOPSIS methods, which results in less debugging cost, high strength and high resistance at elevated temperatures.

\section{REFERENCES}

CHEN, S. J.; HWANG, C. L. (1992) Fuzzy multiple attribute decision making methods and applications, Lecture notes in economics and mathematical systems. Springer, Berlin Heidelberg New York.

DENG, J. L. (1989), Introduction to grey system theory. Grey Syst.1, p. 1-24 HAMADE, R. F.; ISMAIL, F. (2005) A case for aggressive drilling of aluminum. Journal of Materials Processing Technology, n. 166, p. 86-97. 
INDEPENDENT JOURNAL OF MANAGEMENT \& PRODUCTION (IJM\&P)

http://www.ijmp.jor.br

v. 6, n. 2, April - June 2015

ISSN: 2236-269X

DOI: 10.14807/ijmp.v6i2.283

HWANG, C. L.; YOON, K. (1982) Multiple attribute decision making -methods and applications - a state of art survey, Springer, Berlin Heidelberg New York.

KO, S. L.; LEE, J, K. (2001), Analysis of burr formation in drilling with a new-concept drill, Journal of Material Processing Technology, n. 113, p. 392-398.

KUMAR, D. S.; SUMAN, K. N. S. (2014) Selection of Magnesium Alloy by MADM Methods for Automobile Wheels, International Journal of Engineering and Manufacturing, n. 2, p. 31-41, August. DOI:10.5815/ijem.2014.02.03.

LAUDERBAUGH, L. K. (2008), Analysis of the effects of process parameters on exit burrs in drilling using a combined simulation and experimental approach, Journal of Material Processing Technology.

MONTGOMERY, D. C. (2007) Design and Analysis of Experiments, $5^{\text {th }}$ Edition John Wiley.

OLSON, D. L. (2004) Comparison of weights in TOPSIS models, Math Compute Model n. 40, p. 721-727.

PANDE, S. S.; RELEKAR, H. P. (1986), Investigations on Reducing Burr Formation in Drilling, International Journal of Machine Tool Design Researches, n. 26, p. 3339-348.

SAATY, T. L. (2000) Fundamentals of decision making and priority theory with AHP, RWS Publications, Pittsburg.

YOON, Y. P.; HWANG, C. L. (1995) Multiple attribute decision making, SAGE Publications, Beverly Hills. 